\title{
MODEL PENINGKATAN MUTU PENDIDIKAN MELALUI SUPERVISI AKADEMIK BERBASIS WEB
}

\section{Prihayuda Tatang Aditya ${ }^{1}$, Bambang Ismanto ${ }^{2}$}

Universitas Kristen Satya Wacana, Indonesia

Email: adrielyudha20@gmail.com

\section{Info Artikel}

Sejarah Artikel:

Diserahkan 27 Mei 2020

Direvisi 13 November 2020

Disetujui 13 November 2020

Keywords:

quality assurance,

models,

academic supervision,

website

\section{Abstract}

Aims of this study explain 1) the process of implementing academic supervision that has been running in the city of Salatiga; 2) how to develop a web-based academic supervision model in improving the quality of education; 3) and find out the results of the effectiveness of web-based academic supervision models in improving the quality of education through limited trials.

This type of research is Research and Development $(R \& D)$. This research development step uses the Borg \& Gall model which is integrated with the PLOMP model. Data collection techniques using interviews and questionnaires. Data analysis techniques were obtained from interviews and analyzed using qualitative descriptive techniques according to Miles and Huberman consisting of data (1) data reduction; (2) data presentation; and (3) conclusions and verification.

The results from the questionnaire are calculated to get an average value. Limited trials were conducted by 5 supervisors and 5 teachers with an average yield of $89.92 \%$ for supervisors in the excellent category and $89 \%$ for the excellent teacher category. Judging from the results of limited trials, this study was declared effective for use.

\begin{abstract}
Abstrak
Tujuan penelitian ini yaitu menjelaskan 1) proses pelaksanaan supervisi akademik yang sudah berjalan di kota Salatiga; 2) cara pembuatan pengembangan model supervisi akademik berbasis web dalam peningkatan mutu pendidikan; 3) dan mengetahui hasil keefektifan model supervisi akademik berbasis web dalam peningkatan mutu pendidikan melalui uji coba terbatas.

Jenis penelitian ini adalah Research and Development (R\&D). Langkah pengembangan penelitian ini menggunakan model Borg \& Gall yang terintegrasi dengan model PLOMP. Teknik pengumpulan data menggunakan wawancara dan kuesioner. Teknik analisis data diperoleh dari wawancara dan dianalisis menggunakan teknik deskriptif kualitatif menurut Miles dan Huberman yang terdiri dari data (1) reduksi data; (2) penyajian data, dan (3) penarikan kesimpulan dan verifikasi.

Hasil dari kuesioner dihitung untuk mendapatkan nilai rata-rata. Uji coba terbatas dilakukan oleh 5 supervisor dan 5 guru dengan hasil rata-rata 89,92\% untuk supervisor dalam katagori amat baik dan $89 \%$ untuk guru katagori amat baik. Dilihat dari hasil uji coba terbatas maka penelitian ini dinyatakan efektif untuk digunakan.
\end{abstract}


Prihayuda Tatang Aditya, Bambang Ismanto

MODEL PENINGKATAN MUTU PENDIDIKAN MELALUI SUPERVISI AKADEMIK ...

REFLEKSI EDUKATIKA : Jurnal Ilmiah Kependidikan, Volume 11, Nomor 1, Desember 2020, hlm. 70-78

\section{PENDAHULUAN}

Pendidikan merupakan bentuk layanan serta hak sebagai umat manusia yang sudah diselenggarakan oleh pemerintah untuk membentuk pengetahuan, sikap dan perilaku manusia untuk menjadi lebih baik. Hal ini tersirat dalam Undang-undang RI Nomor 20 Tahun 2003 tentang Sistem Pendidikan Nasional pasal 11 ayat 1 disebutkan bahwa setiap warga negara Indonesia memiliki hak untuk mendapatkan layanan pendidikan tanpa adanya diskriminasi sehingga peserta didik dapat mengembangkan kapabilitas akademik, sosial, budaya, keagamaan serta akhlak yang baik dengan melalui proses usaha sadar dan terencana.

Tercapainya tujuan pendidikan tidak lepas dari pengelolaan pada lembaga pendidikan itu sendiri. Pengelolaan pendidikan meliputi perencanaan, pengorganisasian, pengarahan, dan pengendalian sumber daya pendidikan. Sehingga diharapkan tujuan pendidikan dapat tercapai secara efektif, efisien, mandiri, dan akuntabel. Sumber daya pendidikan pada dasarnya merupakan salah satu faktor paling penting yang harus dimiliki oleh lembaga dalam keterlaksanaan aktivitas eskalasi pendidikan.

Eskalasi sumber daya manusia menjadi tanggung jawab seorang guru. Sehingga kapabilitas guru menjadi aset utama dalam mendoktrin manusia memiliki visi, misi dan tujuan dalam hidupnya. Guru merupakan profesi profesional yang memiliki kewajiban utama mengajar, motivator, melatih, mengarahkan menilai, serta mengevaluasi (Suprih Danurwati, 2015).

Guru adalah pelaku dalam pengendalian tingkat satuan pendidikan (sekolah). Selain sebagai pelaku pembelajaran, guru juga bertugas penting dan strategis dalam manajemen sumber daya sekolah. Banyak program intra dan ekstra kurikuler yang menjadi bagian dari fasilitas sekolah yang sudah dipersiapkan, diaplikasikan, diamati dan dievaluasi terhadap guru.

Guru yang menjadi kepala sekolah diberi tugas mengelola dalam perwujudan visi, misi dan tujuan sekolah (Ismanto, 2014). Sebagai pelaku utama dalam peningkatan mutu pembelajaran, guru melaksanakan supervisi akademik sebagai bentuk penilaian dan bimbingan dalam meningkatkan profesinya. Usman (2010) menyatakan bahwa satuan pendidikan wajib menerapkan manajemen sekolah yang baik salah satunya supervisi akademik. Hal tersebut didukung oleh Setiardi dan Munir (2018) bahwa untuk mencapai tujuan Pendidikan maka perlu ditopang oleh beberapa komponen penting antara lain input, kurikulum, guru, tenaga pendidikan, sarana prasarana dan pola manajemen yang baik.

Supervisi akademik merupakan koreksi dan pengembangan pembelajaran serta pelayanan pembelajaran sehingga terus dilakukan perbaikan pembelajaran (Mukhtar, 2010). Senada dengan hal itu, supervisi merupakan upaya dalam meningkatkan kapabilitas profesionalitas kinerjanya, pelaksanaan supervisi bukan mengarah pada peningkatan peserta didiknya, namun lebih kepada pendidiknya (Sagala, 2010a).

Pelaksanaan supervisi akademik terdiri dari kepala sekolah sebagai supervisor dan guru. Kepala sekolah sebagai supervisor wajib memiliki sifat objektif, demokrasi, kooperatif, kemampuan menjaga hubungan yang baik terhadap guru dan harus mengikuti prosedur. Artinya ada perencanaan, pelaksanaanya berdasarkan metode dan model yang sesuai, adanya tindak lanjut. Sehingga setelah dilakukan supervisi akan terjadi peningkatan dalam kapabilitas guru dalam mendidik. Prihono dan Supahar (2018) juga berpendapat bahwa kinerja guru merupakan hasil pencapaian kegiatan pembelajaran yang telah dilakukan di dalam dan di luar kelas. Kepala sekolah dalam melaksanakan supervisi terhadap guru juga menggunakan teknik-teknik tertentu dalam pelaksanaan supervisi yang bermanfaat. Menurut Su'ad (2017) kepala sekolah dalam pengelolaan sekolah juga harus mampu menghindarkan adanya konflik sosial dan mewujudkan sekolah yang saling menghargai dan menghormati antar warga sekolah baik guru, siswa, kepala sekolah, komite sekolah dan sebagainya dengan peran dan mekanisme yang jelas.

Pelaksanaan supervisi di Indonesia masih belum memberikan kontribusi yang maksimal. Keadaan ini terjadi karena problema yang dialami guru dari keadaan latar belakang pendidikan berbeda-beda, penyesuaian yang belum profesional, pencapaian dan kreativitas, kapabilitas seorang pemimpin, keadaam psikologis dan profesionalisme mendidik. Menurut (Sagala, 2010b) bahwa sebagian pendidik belum merasakan kehadiran seorang kepala sekolah sebagai supervisor dalam memberikan penilaian, motivator dan pelayanan yang maksimal, pelaksanaannya banyak yang tidak memberikan solusi atas permasalahan yang 
Prihayuda Tatang Aditya, Bambang Ismanto

MODEL PENINGKATAN MUTU PENDIDIKAN MELALUI SUPERVISI AKADEMIK ...

REFLEKSI EDUKATIKA : Jurnal Ilmiah Kependidikan, Volume 11, Nomor 1, Desember 2020, hlm. 70-78

dialami pendidik dan supervisor tidak mengusai teknik supervisi dengan benar.

Sehingga dalam hal ini, banyak faktor yang mempengaruhi sedikitnya kontribusi pelaksanaan supervisi akademik untuk menambah kapabilitas seorang pendidik, pembuatan aturan yang mendukung fungsi tugas kepala sekolah tidak jelas, kualitas kemampuan kepala sekolah tidak sesuai yang dipersyaratkan sebagai supervisor, perlakuan birokrasi yang tidak menempatkan kepala sekolah sebagai penjamin mutu guru disekolahnya, dukungan dana dan fasilitas dalam pelaksanaan supervisi belum maksimal, bahkan kehadiran supervisor tidak dibutuhkan oleh guru. Berdasarkan data observasi terhadap supervisor/kepala sekolah bahwa pelaksanaan supervisi akademik menimbulkan rasa grogi, tegang dan guru yang merasa siap untuk di supervisi akan lebih siap dibandingkan dengan guru yang tidak tertib akhirnya menjadi beban.Temuan ini jika dibiarkan akan berdampak pada kualitas kemampuan seorang guru serta layanan pengajaran yang kurang baik yang didapat oleh peserta didik. Dampaknya hasil output peserta didik tidak sesuai dengan tujuan yang di harapkan.

Berdasarkan permasalahan di atas, peneliti merasa perlu melakukan penelitian dan pengembanagan (Research \& Development) dengan mengembangkan model peningkatan mutu pendidikan melalui supervisi akademik berbasis web. Hasil wawancara menunjukkan bahwa pemanfaatan teknologi baik, jika dilihat akan ada dampak positif dan negatifnya. Di era sekarang pengembangan supervisi online diharapkan dapat membantu proses supervisi akademik dan lebih lagi apabila terdapat blended supervisi. jadi bisa berkolaborasi online dan konvensional serta bagus dilaksanakan jika secara profesional, objektif, akuntabel dan transparan.

Beberapa penelitian yang serupa yaitu penelitian David, Totok, dan Achmad (2016) menunjukkan bahwa model supervise dinyatakan efektif untuk meningkatkan kompetensi guru dalam pemanfaatan ICT dan model supervisi tersebut sangat direkomendasikan oleh kepala sekolah dalam melakukan supervisi terhadap guru. Penelitian Andani, Arief, dan Murwatiningsih (2017) disarankan oleh validator untuk di ujicobakan dengan skala lebih luas artinya bisa di uji cobakan dengan guru bidang studi lainya. Selanjutnya penelitian oleh Albar
AM (2012) merancang sistem pengawasan elektronik e-supervision untuk menciptakan lingkungan kolaborasi pendidik antara supervisor dan guru yang mencangkup ketrampilan, pengalaman, sikap, dan strategi pengajaran. Penelitian Mathisen menghasilkan delapan aspek peningkatan kualitas: pengamatan yang lebih baik, motivasi yang lebih kuat, umpan balik yang lebih baik, peningkatan berbagi pendapat, peningkatan koherensi, struktur yang lebih baik, persiapan yang lebih baik, dan refleksi yang meningkat.

Hasil penelitian yang relevan menunjukkan bahwa pentingnya pelaksanaan supervisi akademik maupun klinis adalah untuk meningkatkan kapabilitas seorang pendidik. Dalam pelaksanaanya dibantu dengan teknologi sebagai media perekam dari proses implementasi supervisi, supaya supervisor/kepala sekolah akan lebih teliti dalam menilai dengan melihat hasil video yang sudah terekam. Tujuan penelitian ini adalah untuk mendeskripsikan proses pelaksanaan supervisi akademik yang sudah berjalan di kota Salatiga, menjelaskan cara pembuatan pengembangan Model peningkatan mutu pendidikan melalui supervisi akademik berbasis web dan menyusun supervisi akademik berbasis web dalam upaya peningkatan mutu pendidikan.

\section{METODE PENELITIAN}

Penelitian ini merupakan penelitian dan pengembangan (Research and Development). Penelitian ini menerapkan tahapan dari Borg \& Gall, namun dalam tahapan ini disederhanakan menjadi tiga tahapan, antara lain studi pendahuluan, pengembangan dan evaluasi. Pada tahap pengembangan pembuatan model supervisi akademik berbasis web menggunakan tahapan PLOMP, model tersebut memiliki 5 tahapan yang terdiri dari investigasi awal, perancangan, realisasi, pengujian produk dan evaluasi, implementasi. Lebih jelasnya bisa dilihat gambar berikut. 
Prihayuda Tatang Aditya, Bambang Ismanto

MODEL PENINGKATAN MUTU PENDIDIKAN MELALUI SUPERVISI AKADEMIK ...

REFLEKSI EDUKATIKA : Jurnal Ilmiah Kependidikan, Volume 11, Nomor 1, Desember 2020, hlm. 70-78

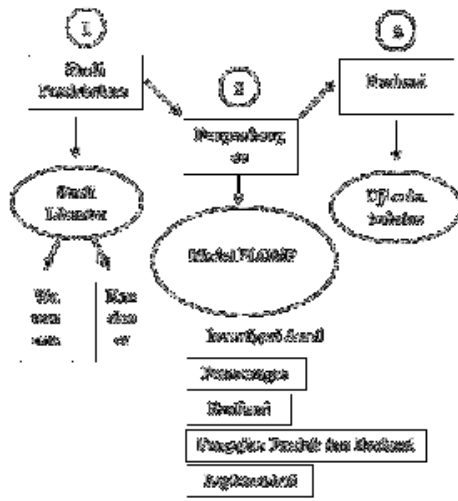

Gambar 1. Prosedur Borg \& Gall terintegrasi dengan PLOMP

Teknik pengumpulan data menggunakan wawancara dan kuesioner. Untuk melengkapi data yang belum terungkap melalui wawancara penulis menggunakan lembar kuesioner dengan skala Guttman, dalam pelaksanaanya responden hanya menjawab "ya" atau "tidak". Teknik ini bertujusn untuk mendapatkan jawaban yang tegas dan singkat.

Uji validitas produk penelitian pengembangan berupa model peningkatan mutu pendidikan melalui supervisi akademik berbasis web melibatkan 2 orang validator ahli yaitu ahli model, ahli instrumen penilaian supervisi akademik, serta modul pedoman kepala sekolah dan guru.

Hasil yang diperoleh dari wawancara dan dianalisis menggunakan teknik deskriptif kualitatif menurut Miles dan Huberman yang terdiri dari data (1) reduction/ reduksi data; (2) data display penyajian data, dan (3) conclusion drawing/verification penarikan kesimpulan dan verifikasi (Sugiyono, 2015) Hasil Angket dianalisis untuk memperoleh skor, rata-rata, dan presentase. Hasil angket diklasifikasikan melalui perhitungan dengan kelas interval.

Hasil uji terbatas model supervisi akademik dengan berbasi web menggunakan analisis metode kuantitatif. Dalam metode kuantitatif disajikan instrumen lembar pendapat oleh lima kepala sekolah dan lima guru di Jawa Tengah. Hasilnya akan di olah untuk mencari prosentase rata-rata setiap aspek dan jumlah keseluruhan persentase rata-rata semua aspek.

\section{HASIL DAN PEMBAHASAN Hasil Analisis Pengumpulan Informasi 1. Perencanaan}

Perencanaan supervisi akademik dari hasil penyebaran lembar kuesioner diperoleh hasil rata-rata $87,33 \%$ dari 5 pertanyaan yang diajukan dengan 30 narasumber. Berikut ini adalah salah satu hasil pendapat dari narasumber.

"Apa sajakah teknik yang digunakan

untuk supervisi akademik?"

"Menurut saya, bahwa pelaksanaan

supervisi akademik menggunakan

teknik wawancara, wawancara

individual dan kelompok, observasi

kelas dan umpan balik".

\section{Pelaksanaan}

Tahap selannjutnya Tahap selanjutnya penulis mengelompokan beberapa pertanyaan untuk angket pada aspek pelaksanaan. Dari hasil rata-rata yang diperoleh dari 5 pertanyaan dari aspek tersebut mendapatkan nila rata-rata sebesar $86 \%$ responden menjawab setuju. Selain dari hasil kuesioner penulis mendapatkan hasil wawancara terhadap pelaksanaan supervisi akademik. Langkah-langkah pelaksanaan supervisi akademik terdapat 3 tahapan yaitu perencanaan, penyampaian informasi dan pembuatan jadwal supervisi akademik. Selain itu pelaksanaanya diawali dengan percakapan untuk mengetahui berbagai kebutuhan guru, mengadakan kesepakatan pertemuan, melakukan observasi, menganalisis data observasi, pertemuan akhir dengan diskusi untuk menentukan tindak lanjut.

3. Evaluasi

Kegiatan evaluasi penulis mendapatkan hasil dari wawancara dalam pembahasan masalah yang sering dihadapi kepala sekolah dalam melakukan supervisi akademik secara konvensional antara lain terjadi perencanaan kurang siap, sikap guru yang belum paham, sistem pengolahan dan analisis data yang kurang, kepala sekolah/supervisor kurang berani terhadap guru. Selanjutnya ada beberapa kendala yang dihadapi kepala sekolah yaitu terkait dengan penguasaan materi yang sifatnya khusus, misalnya materi kurikulum, penilaian K13 dll. hal ini terjadi karena dalam pelaksanaan supervisi yang terlaksana hanya bersifat umum saja. Di era abad 21 pelaksanaan supervisi secara konvensional masih banyak dilakukan oleh beberapa supervisor, artinya belum memanfaatkan teknologi supaya lebih efektif. Hasilnya bahwa pelaksanaan supervisi secara 
Prihayuda Tatang Aditya, Bambang Ismanto

MODEL PENINGKATAN MUTU PENDIDIKAN MELALUI SUPERVISI AKADEMIK ...

REFLEKSI EDUKATIKA : Jurnal Ilmiah Kependidikan, Volume 11, Nomor 1, Desember 2020, hlm. 70-78

konvensional ada beberapa kelemahan, antara lain guru tidak bebas mengutarakan kekuranganya dan kepala sekolah juga kurang berani.

\section{Tindak Lanjut}

Pada kegiatan tindak lanjut, penulis memberikan beberapa pertanyaan yang berkaitan dengan model supervisi akademik berbasis web. Dalam hal ini penulis ingin mengetahui pendapat/argumen dari responden terkait dengan model tersebut. Ada tiga pertanyaan yang di berikan untuk responden, berikut pertanya 1) Pemanfaatan teknologi sebagai supervisi akademik, dari hasil pertnyaan ini sebanyak 20 responden menjawab setuju dan menunjukkan nilai $66,70 \%$ namun pada hal ini responden dalam memanfaatkan teknologi contohnya menggunkan whatsapp. Bukan aplikasi khusus untuk supervisi akademik; 2) Penggunaan web sebagai model supervisi akademik, pada hal ini responden hanya menjawab setuju sebanyak 7 orang dan nilanya $23,30 \%$. Sehingga banyak responden yang belum memanfaatkan aplikasi khusus untuk supervisi akademik berbasis web. Penyebabnya karena sekolahan belum banyak yang mempunyai aplikasi tersebut. 3) Kepala sekolah sudah menguasai model supervisi akademik berbasis web, untuk hak ini hasilnya masih banyak kepala sekolah yang belum menguasai model supervisi akademiik berbasis web disebabkan belum diterapkanya model tersebut pada sekolah.

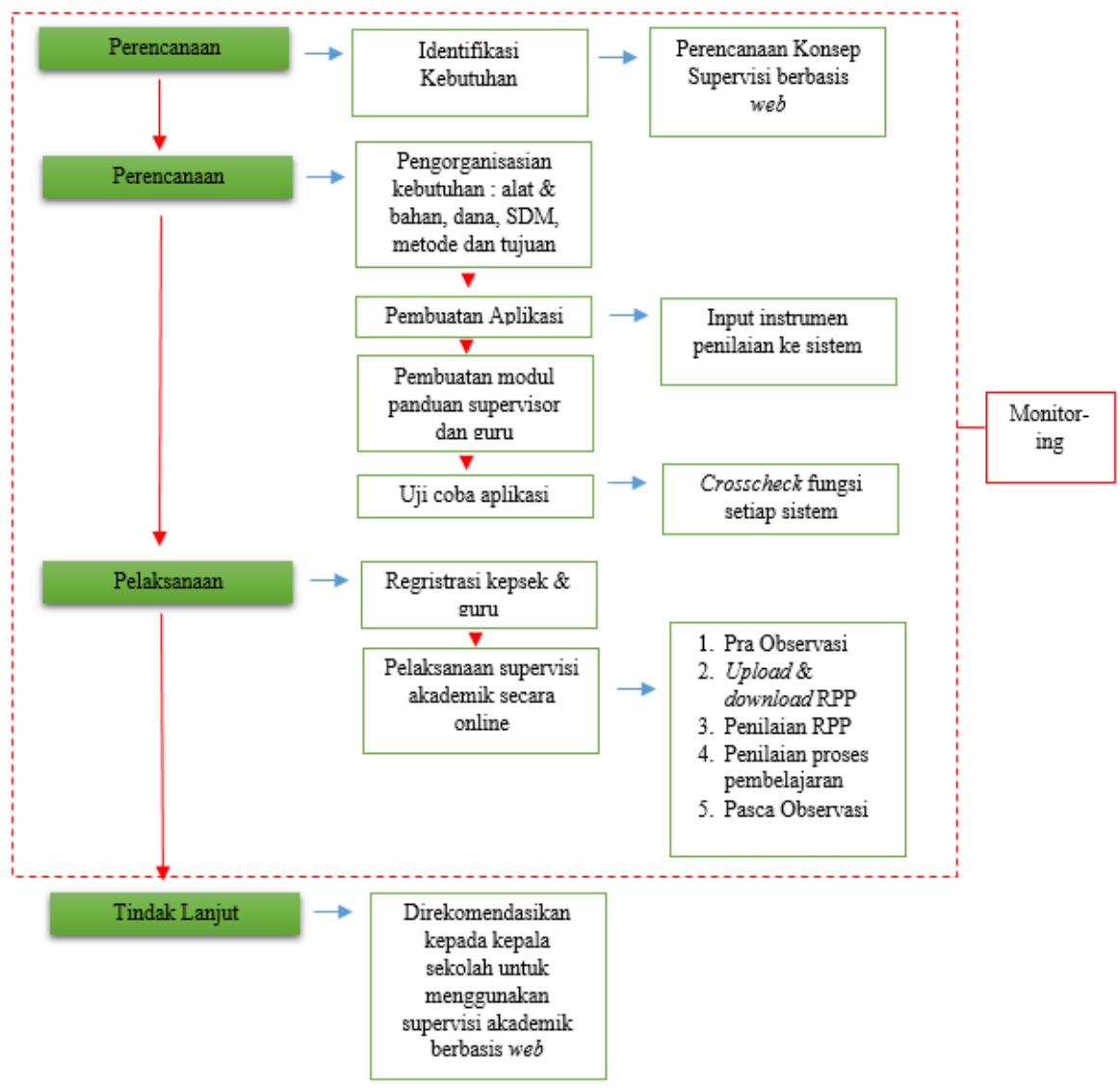

Gambar 2. Model Supervisi Akademik Berbasis Web

\section{Pengembangan Model Supervisi Akademik Berbasis Web}

Penelitian pada pengembangan model supervisi akademik berbasis web menggunakan tahapan model PLOMP sebagai panduan untuk menyusunya. Berikut uraian tahapanya.

1. Investigasi Awal 
Prihayuda Tatang Aditya, Bambang Ismanto

MODEL PENINGKATAN MUTU PENDIDIKAN MELALUI SUPERVISI AKADEMIK ...

REFLEKSI EDUKATIKA : Jurnal Ilmiah Kependidikan, Volume 11, Nomor 1, Desember 2020, hlm. 70-78

Pada tahap pertama penulis mempersiapkan kerangka konsep model yang akan dibuat, alat dan isi kontenya yang dibutuhkan dalam pengembangan nantinya. Alat yang dimakasud antara lain laptop yang fungsinya untuk mengerjakan project model supervisi akademik berbasis web. Laptop ini fungsinya sangat penting dan utama. Untuk konten atau isi didalam model ini berisi lembar penilaian yang nantinya akan di inputkan penulis ke dalam web. Sehingga model ini pelaku atau supervisor dalam melaksanakan penilaian bisa secara online.

2. Perancangan

Tahap yang kedua merupakan tahap perancangan, tahap ini dimana penulis memulai untuk pembuatan medel berdasarkan kerangka konsep model dan alat yang sudah dipersiapkan sebelumnya. Hasil model berupa website untuk kepala sekolah dan guru. Dalam pelaksanaanya supervisor dan guru harus login kedalam website berdasarkan akun masing-masing. Berikut contoh gambar halaman website untuk supervisor dan guru.

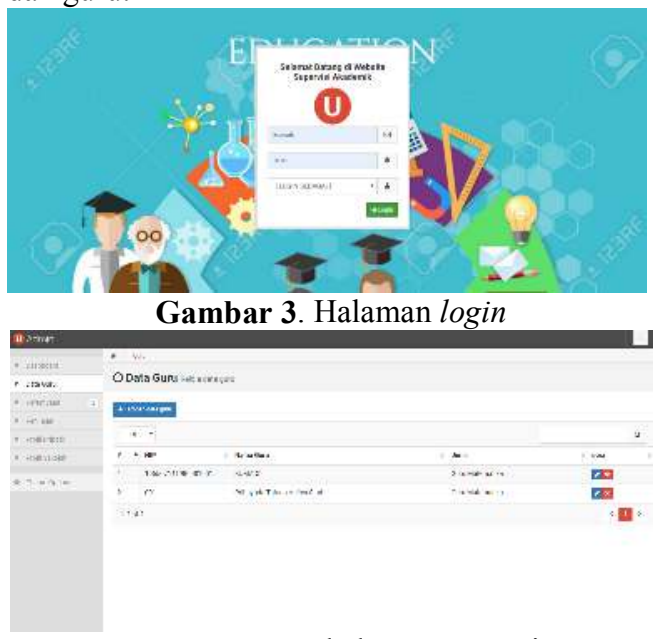

Gambar 4. Menu halaman supervisor

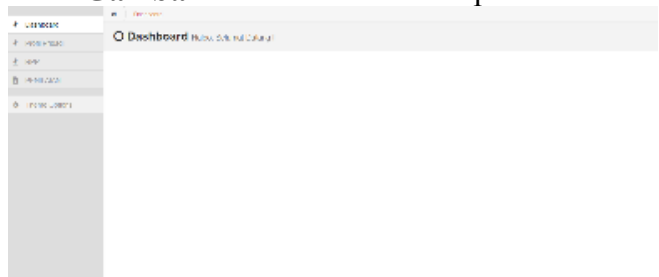

Gambar 5. Halaman menu utama guru

\section{Realisasi}

Tahap realisasi merupakan tahap uji coba hasil pengembangan yang sudah selesai dibuat pada tahap perencanaan. Penulis pada tahap ini di ujicobakan secara mandiri, artinya penulis menguji cobakan media yang sudah dibuat secara pribadi. Fungsinya untuk mengecek setiap kinerja dari beberapa menu yang sudah dibuat. Ketika ada eror maka pada tahap ini penulis juga bisa langsung merevisinya kembali. Sehingga ketika penulis ingin memvalidasi model ini harapanya tidak ada banyak fungsi yang eror.

4. Pengujian Produk dan Evaluasi

Tahap ini dilakukan validasi model terhadap ahli dibidangnya. Validasi model dilakukan oleh Dr. Kristoko Dwi Hartomo, M. Kom dan untuk validasi modul panduan oleh Dr. Yari Dwi Kurnaningsih, M.Pd. hasil validasi model dan modul panduan dapat dilihat pada gambar berikut ini.

Tabel 1. Hasil Validasi Model

\begin{tabular}{|c|c|c|c|}
\hline No & Aspek & Persentase & Kriteria \\
\hline 1. & Pemrograman & $90 \%$ & Sangat Valid \\
\hline 2. & Penggunan & $100 \%$ & Sangat Valid \\
\hline 3. & Tampilan & $94,28 \%$ & Sangat Valid \\
\hline 4. & Keterlaksanaan & $100 \%$ & Sangat Valid \\
\hline
\end{tabular}

Secara umum supervisi akademik berbasis web dapat berfungsi dengan baik dan akan dapat mempermudah supervisi akademik. Akan lebih baik jika output laporan ditambahkan berbentuk file pdf".

Tabel 2. Hasil Validasi Modul Panduan

\begin{tabular}{cccc}
\multicolumn{4}{c}{ Supervisor dan Guru } \\
\hline No & \multicolumn{1}{c}{ Validasi } & Persentase & Kriteria \\
\hline 1. & $\begin{array}{l}\text { Panduan kepala } \\
\text { sekolah }\end{array}$ & $75 \%$ & Valid \\
2. & Panduan Guru & $75 \%$ & Valid \\
\hline Jumlah rata-rata & $75 \%$ & Valid \\
\hline
\end{tabular}

Dari hasil validasi modul panduan supervisor dan guru memperoleh prosentase ratarata sebesar $75 \%$ sehingga dapat masuk dalam kriteria Valid, atau dapat digunakan namun perlu direvisi kecil. Berikut penjabaran catatan dari validator yang perlu direvisi oleh penulis. Pada halaman pra observasi dan pasca observasi validator memeberikan catatan jika guru harus ada tempat untuk berdiskusi dengan kepala sekolah artinya tidak hanya kepala sekolah yang diberikan ruang untuk bertanya. Rencana tidak lanjut pada supervisi akademik berbasis web adalah penerapan atau implementasi model ini untuk dipakai dalam pelaksanaan supervisi akademik. Pada penelitian ini terbatas sampai uji 
Prihayuda Tatang Aditya, Bambang Ismanto

MODEL PENINGKATAN MUTU PENDIDIKAN MELALUI SUPERVISI AKADEMIK ...

REFLEKSI EDUKATIKA : Jurnal Ilmiah Kependidikan, Volume 11, Nomor 1, Desember 2020, hlm. 70-78

coba terbatas dengan menampung pendapat dari kepala sekolah dan guru mengenai model supervisi tersebut. Revisi tidak hanya untuk RPP saja, melainkan untuk proses pembelajaran melalui pengulangan penilaian proses pembelajaran.

Dalam umpan balik dilakukan pada tahap pasca observasi, dimana pada tahap ini guru bisa mengutarakan beberapa pengalaman yang sudah di alamai selama proses supervisi berlangsung dan tahap ini supervisor bisa memberikan masukan untuk guru.
Tahap observasi dilaksanakan secara langsung. Karena peneiti menyadari masih terbatas dalam membuat model untuk penambahan ruang chatting/diskusi serta memberikan ruang untuk upload video conference.

5. Implementasi

Pada tahap implementasi sama dengan tahap evaluasi yaitu dengan uji terbatas model. Hasil penelitian menyatakan bahwa kelima guru yang diteliti telah melakukan persiapan dan perencanaan pembelajaran dengan baik.

Tabel 3. Hasil Uji Terbatas Model untuk Supervisor

\begin{tabular}{ccccccc}
\hline Nama & $\begin{array}{c}\text { Panduan } \\
\text { dan } \\
\text { Informasi }\end{array}$ & $\begin{array}{c}\text { Konten/ } \\
\text { penilaian }\end{array}$ & $\begin{array}{c}\text { Kinerja } \\
\text { program } \\
\text { model }\end{array}$ & $\begin{array}{c}\text { Umpan } \\
\text { balik } \\
\text { model }\end{array}$ & $\begin{array}{c}\text { Rata-rata } \\
\text { persentase }\end{array}$ & Kriteria \\
\hline SU & $100 \%$ & $100 \%$ & $84,44 \%$ & $100 \%$ & $96,11 \%$ & $\mathrm{AB}$ \\
\hline SG & $88 \%$ & $83,5 \%$ & $95 \%$ & $93,3 \%$ & $89,95 \%$ & $\mathrm{AB}$ \\
\hline YH & $92 \%$ & $84,21 \%$ & $86,66 \%$ & $80 \%$ & $85,7 \%$ & $\mathrm{~B}$ \\
\hline YI & $100 \%$ & $97,89 \%$ & $95,5 \%$ & $100 \%$ & $98,34 \%$ & $\mathrm{AB}$ \\
\hline $\mathrm{KP}$ & $76 \%$ & $82,1 \%$ & $80 \%$ & $80 \%$ & $79,52 \%$ & $\mathrm{~B}$ \\
\hline
\end{tabular}

Tabel 4. Hasil Uji Coba Terbatas Model untuk Guru

\begin{tabular}{ccccccc}
\hline Nama & $\begin{array}{c}\text { Panduan } \\
\text { dan } \\
\text { Informasi }\end{array}$ & $\begin{array}{c}\text { Konten/ } \\
\text { penilaian }\end{array}$ & $\begin{array}{c}\text { Kinerja } \\
\text { program } \\
\text { model }\end{array}$ & $\begin{array}{c}\text { Umpan } \\
\text { balik } \\
\text { model }\end{array}$ & $\begin{array}{c}\text { Rata-rata } \\
\text { persentase }\end{array}$ & Kriteria \\
\hline $\mathrm{DP}$ & $88 \%$ & $97,57 \%$ & $86,66 \%$ & $90 \%$ & $90,55 \%$ & $\mathrm{AB}$ \\
\hline $\mathrm{IR}$ & $96 \%$ & $96 \%$ & $93 \%$ & $95 \%$ & $95 \%$ & $\mathrm{AB}$ \\
\hline $\mathrm{MK}$ & $76 \%$ & $82,1 \%$ & $88,8 \%$ & $95 \%$ & $85,47 \%$ & $\mathrm{~B}$ \\
\hline $\mathrm{AL}$ & $96 \%$ & $88,42 \%$ & $95,5 \%$ & $100 \%$ & $94,98 \%$ & $\mathrm{AB}$ \\
\hline $\mathrm{AG}$ & $84 \%$ & $67,36 \%$ & $75,55 \%$ & $90 \%$ & $79,22 \%$ & $\mathrm{~B}$ \\
\hline & & Jumlah & & & $89 \%$ & $\mathrm{AB}$ \\
\hline
\end{tabular}

Supervisi pendidikan masih menjadi proses yang harus dilaksanakan dalam meningkatkan mutu pendidikan di Indonesia. Salah satu supervisi yang sangat penting yaitu supervisi akademik, karena mengingat akan hal berhasilnya atau peningkatan mutu pendidikan tidak terlepas dari peran seorang pendidik sebagai profesi yang sangat mulia. Mengingat kerja seoang guru salah satunya adalah mencerdaskan kehidupan bangsa Indonesia yang tertuang pada pembukaan UUD 1945.

Guru memiliki peran yang sangat penting sebagai pembimbing, fasilitator, mediator dan motivator. Keempat peran tersebut jika dalam pelaksanaanya tidak semudah apa yang dipikirkan, karena setiap siswa memiliki karakter yang berbeda-beda dan seorang guru harus bisa menjadi empat peran tersebut pada semua siswanya. Supaya tugas dan peranya dapat dilaksanakan dengan baik, maka guru harus menguasai kompetensi profesionalisme, pedagogik, sosial dan pengembangan diri.

Untuk mengusai kompetensi tersebut, maka guru harus mengikuti pelaksanaan supervisi, salah satunya pada bidang akademiknya. Aribowo, et. al (2020) menyebut bahwa supervisi akademik mempunyai kontribusi yang sangat penting dalam 
rihayuda Tatang Aditya, Bambang Ismanto

MODEL PENINGKATAN MUTU PENDIDIKAN MELALUI SUPERVISI AKADEMIK ...

REFLEKSI EDUKATIKA : Jurnal Ilmiah Kependidikan, Volume 11, Nomor 1, Desember 2020, hlm. 70-78

meningkatkan kompetensi profesional guru dalam kualitas pengajaran yang dilakukan oleh guru di sekolah. Senada dengan pendapat Kholid, et. al (2020) menyatakan bahwa pelaksaan supervisi berpengaruh signifikans terhadap kinerja guru. Diharapkan dalam pelaksanaan supervisi akademik dapat meningkatkan kompetensi guru semakin meningkat. Namun pada kenyataanya pelaksanaan supervisi akademik justru tidak sesuai yang diharapkan, berdasarkan wawancara terhadap kepala sekolah selaku supervisor mengatakan bahwa dalam pelaksanaanya kadang guru merasa terbeban dengan adanya supervisi akademik dan guru tidak berani untuk mengungkapkan kekurangnya sehingga kepala sekolah tidak mengetahui masalah yang dialami guru tersebut. Jika dari sisi kepala sekolah sebagai supervisor kenyataanya malah grogi dan kurang berani memberikan masukan dan solusi yang berguna untuk memperbaiki kekurangan guru. Diantara masalah diatas maka penulis mengembangkan model supervisi akademik berbasis web.

Model tersebut memanfaatkan teknologi internet sebagai kebutuhan utama dalam pelaksanaan supervisi akademik. Dengan memanfaatkan teknologi dapat membuat efektif dan dapat mengutarakan banyak pendapat melalui tulisan yang akhirnya dapat dilihat dan dibaca langsung oleh guru yang bersangkutan. Hal ini menjawab permasalahan diatas jika antara kepala sekolah dan guru saling kurang berani mengungkapkan pendapat secara tatap muka.

Dalam pengembangan model ini penulis memakai model Borg dan Gall yang terintegrasi dengan model PLOMP sebagai acuan langkah langkah dalam pengembangan model ini. Selanjutnya mevalidasi model dan modul panduan terhadap para ahli dibidangnya. Setelah divalidasi model direvisi oleh penulis berdasarkan catatan dari ahli validasi. Selanjutnya model diuji cobakan secara terbatas oleh lima kepala sekolah dan guru. Dalam uji coba ini hasilnya menunjukkan $89,92 \%$ untuk kepala sekolah dan $89 \%$ terhadap guru dengan predikat keduanya 'amat baik". Artinya bahwa pengembangan model supervisi akademik berbasis web layak untuk digunakan.

\section{SIMPULAN}

1. Pelaksanaan supervisi akademik di kota Salatiga ada beberapa kelemahan, antara lain sebagai berikut: a. Bagi kepala sekolah masih tidak berani untuk memberikan masukan atau solusi terhadap guru ketika dirasa ada beberapa yang harus di perbaiki.

b. Kepala sekolah sebagai supervisor terkait dengan pengusaan materi yang sifatnya khusus, misalnya materi kurikulum penilaian K13 d1l, penyebabnya dalam pelaksanaan supervisi akademik sebelumnya bersifat umum saja artinya hanya pembinaan saja.

c. Bagi guru, banyak yang belum mempersiapkan diri ketika akan dilaksanakan supervisi akademik, sehingga guru tidak siap dalam pelaksanaanya.

d. Sikap guru yang belum paham tentang supevisi akademik, bisanya guru menganggap supervisi merupakan kegiatan mencari masalah.

2. Model supervisi akadmik berbasis web, memiliki hasil akhir yang berupa model supervisi akademik berbasis web, modul panduan kepala sekolah, dan modul panduan guru. Model dikembangkan menggunakan tahapan Borg dan Gall yang terintegrasi dengan model PLOMP. Khusus untuk acuan mengembangkan model menggunkan tahapan PLOMP. Selanjutnya model dan modul di validasi oleh para ahli dibidangnya untuk memberikan masukan dan menyempurnakan model dan panduan.

3. Tahap selanjutnya uji terbatas terhadap lima kepala sekolah dan lima guru yang ada di kota Salatiga. Data diambil berupa angket respon atau pendapat dari responden dan di rata-rata hasilnya mencapi nilai 89,92\% termasuk kriteria "amat baik" dan untuk guru mencapai nilai 89\% sehingga masuk dalam kriteria "amat baik". Sehingga hasil pengembangan model ini efektif untuk di implementasikan.

\section{DAFTAR PUSTAKA}

Albar AM. An Electronic Supervision System Architecture in Education Environments. 2012; 4 (8):140-149.

Aribowo, Su'ad, dan Madjdi, A.H. 2020. Pengaruh Supervisi Akademik dan pelatihan Penelitian Tindakan Kelas Terhadap Kompetensi Profesional Guru Sekolah Dasar Se-Kecamatan Undaan 
Prihayuda Tatang Aditya, Bambang Ismanto

MODEL PENINGKATAN MUTU PENDIDIKAN MELALUI SUPERVISI AKADEMIK ...

REFLEKSI EDUKATIKA : Jurnal Ilmiah Kependidikan, Volume 11, Nomor 1, Desember 2020, hlm. 70-78

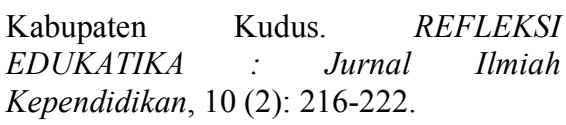

Kholid, Su'ad, \& Madjdi, A.H. 2020. Analysis of Principals Academic Supervision and Teachers Work Motivation Toward The Performance of State Elementary School Teachers In Undaan District Kudus Regency. REFLEKSI EDUKATIKA : Jurnal Ilmiah Kependidikan, 10 (2): 256266.

Mathisen P. Tablets As Adigital Tool In Supervision Of Student teachers , Practical Training. 2016. doi:10.18261/issn.1891-943x-2016-04-02.

David Guntoro, Totok Sumaryanto F, A. R. R. 2016. Pengembangan Model Supervisi Akademik Berbasis Web. Educational Management: Major Themes in Education, 5 (2), 122-128.

Yan Septio, B. A, Arief. Y, M. 2017. Model Supervisi Klinis Berbasis Teknologi Informasi dan Komunikasi Untuk Menigkatkan Kinerja Guru Produktif di Smkn 1 Kota Bima, Educational Management: Major Themes in Education, EM 6 (2): 163-169.

Ismanto, B. (n.d.). The Management of The School Financing (Case Studies on the funding of primary schools in Temanggung District, in Central Java Province, Indonesia). MAKALAH Seminar Nasional, 2014, 2.

Mukhtar, I. 2010. Orientasi Baru Supervisi Pendidikan. Jakarta: Gaung Persada Prees Group.
Pemernendiknas No 13 Tahun 2007 Tentang Kemampuan Kepala Sekolah.

Prihono, E.W., dan Supahar. 2018. The Measurement Of Professional Competency To School Tearchers Achievement at PGRI University Yogyakarta Laboratory. REFLEKSI EDUKATIKA : Jurnal Ilmiah Kependidikan, 8 (2): 114-123.

Sagala, S. 2010a. Supervisi Pembelajaran Dalam Profesi Pendidikan. Bandung: Alfabeta.

Sagala, S. 2010b. Supervisi Pembelajaran Dalam Profesi Pendidikan. Bandung: Alfabeta.

Setiardi, D., dan Munir, M.M. 2018. Model Manajemen Mutu Terpadu Berbasis Multiple Intelegence Pada Sekolah Dasar Unggulan Di Kabupaten Jepara. REFLEKSI EDUKATIKA : Jurnal Ilmiah Kependidikan, 9 (1): 101-106.

Su'ad. 2017. Pengembangan Model Manajemen Sekolah Berbasis Multikultural Pada Sekolah Menengah Atas (SMA) Di EksKaresidenan Pati. REFLEKSI EDUKATIKA : Jurnal Ilmiah Kependidikan, 7 (2): 165-171.

Sugiyono. 2015. Metode Penelitian dan Pengembangan Research and Development. Bandung: Alfabeta.

Suprih Danurwati, S. 2015. Penerapan Supervisi Kunjungan Kelas untuk Meningkatkan Kinerja Guru Sekolah Dasar Negeri. Jurnal Kelola Manajemen Pendidikan, 2, 99-109.

Undang-Undang No 20 Tahun 2003 Sistem Pendidikan Nasional.

Usman, H. 2010. Manajemen Teori, Praktik, dan Riset Pendidikan. Jakarta: Bumi Aksara. 